\title{
Dijital Kimliklerin ve The Circle Filminin Goffman'ın Benlik Sunumu Kuramı Bağlamında Analizi
}

\author{
Sevgi Kavut (Dr.) \\ sevgikavutt@gmail.com
}

Başvuru Tarihi: 13.07.2021

Yayına Kabul Tarihi: 30.09.2021

Yayınlanma Tarihi: 28.10.2021

https://doi.org/10.17680/erciyesiletisim.971135

Öz

Günümüzde iletişim ile ilgili her yapının değişime uğradığı görülmektedir. Dijital iletişim teknolojilerinin önlenemez hızda yükseliși, dijital kimliklerin yaygınlaşması ve pandemi ile birlikte online iletişimde yaşanan artışın bireylerin günlük yaşam aktivitelerinden çalışma biçimlerine, benlik sunumlarından izlenim yönetimi süreçlerine kadar birçok alanı kapsadığına inanılmaktadır. 21.yy'ın ortalarında ve gelecekte toplumumuzun daha yapay zekâya dayalı, büyük veri odaklı ve birbirine bağlı bir dünyada olacağı, sosyal sistemlerin blockchain (blokzinciri) tabanlı bağlantılar ve dağılmış veri tabanlarının bilgi alt yapısında vurgulanacağı belirtilmiștir. Bu makalenin amacı dijital kimlikler ve online iletişim teknolojileriyle yaşanan değişim ve dönüşüm süreçlerini, dijital kimliklerin ve yeni iletişim teknolojilerinin insanların hayatındaki konumunu, benlik sunumlarını Goffman'ın benlik sunumu kuramı bağlamında The Circle (Çember) filminden örnekler ile ortaya koymaktır. The Circle filmi sahneleri ile dijital kimlik ve yeni iletişim teknolojilerinin insan hayatındaki değişim süreçleri örneklendirilmiştir. Sonuç olarak, The Circle filmi analiz edildiğinde Goffman'ın performans, vitrin, takımlar, bölgeler ve bölgesel davranışlar, ayrıksı rollerden muhbir, gözcü ve profesyonel müşteri rolleri, karakter dışı iletişim, izlenim denetimi sanatı kavramlarına ilişkin örnekler bulunmuştur. $\mathrm{Bu}$ makalenin dijital kimlik, dijital iletişim, izlenim yönetimi, benlik sunumları konularında yapılacak çalışmalara katkı sunacağına inanılmaktadır.

Anahtar Kelimeler: İletişim Çalışmaları, Dijital Kimlik, Yeni İletişim Teknolojileri, Film Analizi, The Circle, Benlik Sunumu Kuramı. 


\title{
Digital Identities and The Circle Film Analysis in the context of Goffman's Self Presentation Theory
}

\author{
Sevgi Kavut (Ph.D.) \\ sevgikavutt@gmail.com
}

Date Received: 13.07.2021

Date Accepted: 30.09 .2021

Date Published: 28.10.2021

https://doi.org/10.17680/erciyesiletisim.971135

\begin{abstract}
It is seen that everything related communication has changed. It is believed that increasing unprecedented rate of digital communication technologies, proliferation of digital identities and increasing in online communication with pandemic has included many areas from daily affairs to work styles, from self presentations to impression management processes. In the mid-21st century and in the future it is stated that our society will certainly be in more artificial intelligence-based, big data-based and interconnected world, social systems will be emphasized in the knowledge infrastructure of blockchain-based connections and distributed databases. The aim of this article is to reveal the processes of change and transformation with digital identities and new communication technologies in people's lives, self-presentations with examples from The Circle in the context of Goffman's self presentation theory. The Circle film scenes examplified the process of digital identities and new communication technologies in human life. As a result, when The Circle was analyzed, examples of Goffman's performance, showcase, teams, regions and regional behaviors, discrete roles, whistleblower, scout and professional client roles, out-of-character communication, art of impression control were found. It is believed that this article will contribute to the studies to be carried out in issues of digital identity, digital communication, impression management, self-presentations.
\end{abstract}

Keywords: Communication Studies, Digital Identity, New Communication Technologies, Film Analysis, The Circle, Self-Presentation Theory. 


\section{Giriş}

İletişim, tarih boyunca insan ırkının en derin ihtiyaçlarından biri olmuştur. İyi bir iletişim modern toplumların temelidir (Gallager, 2008, s. 1). Toplumları analogdan dijital modellere dönüştüren, çı̆̆ır açan teknolojilerin gelmesiyle dünya son 20 yıl içinde süregelen bir değişime sahip olmuştur (Al-Khouri, 2014, s. 184). İnternet şu an tüm dünyada insanlar arasında sosyalleşmek için kullanılmaktadır. Sosyal ağlarda ilişkiler dürüstlük, itibar ve diğer kullanıcılar ile karşılıklı olma durumları ile yapılmaktadır (Olivera, Bertolino, Dominguez-Mayo, Jose-Escalona, \& Matteucci, 2020, s. 1).

Yeni teknolojilerin hangi bireylerin kimliklerini tanımladığı ve doğruladığına ilişkin köklü değişiklikler yapması olası olmuştur. Bu teknolojiler kimlik kartı olmadan yasal kimlik tanımlama sağlamak için kullanışlı araçlar olabilir (Beduschi, 2019, s. 4). Dijitalleşme, dijital teknolojilerin daha güçlü kullanımını, dijital platformların artan kullanımını, dijital iş modellerinin artan kullanımını ve firmaların geleneksel süreçlerinin dijitalleşmiş süreçlere dönüşümünü tanımlamaktadır (Bouncken \& Barwinski, 2020, s. 2). Benzersiz bir kavram olan dijitalleşme; artan güçlü bilgi teknolojileri yoluyla olanak sağlanan yeni icatlar, yenilikler ve gelişmelerle bilgi ve süreçlerin dijitalleşmesi anlamına gelmektedir. Günümüzde neredeyse her endüstri dijitalleşmeden etkilenmekte ve yeni olasılıklar yoluyla firsatlar ve tehditlerle yüzleșmektedir (Glaser, Hawlitschek, \& Notheisen, 2019, s. 121). Özellikle pandeminin de etkisiyle dijitalleşme sürecinin hız kazandığı günümüzde birçok işlemin dijital yöntemlerle çözümlenmesi dijital teknolojilere, dijital kimliklere, dijital hizmetlere olan ihtiyacın arttığını ve giderek daha fazla gereklilik halini alacağını düşündürmektedir.

Dijital çă̆ teknolojisinin uzun zamandır insanlığın öğrenme şekli, iletişim kurma biçimleri ve hatta düşünme şekillerine kadar geniş bir yelpazede beklenmedik bir etkiye sebep olduğu ifade edilmiștir. Aynı zamanda teknoloji insanlığın evriminde aktif bir rol oynamıştır (Alves, Natalio, Henriques-Calado, \& Gama, 2019, s. 8). Dijital çağda yeni teknolojiler bireyleri kimlik doğrulama ve kimlik tanımlamaya yöneltmektedir. Bireyin doğum yeri, doğum tarihi, etnik ve ulusal kökeni gibi yaşamsal faktörler ile göz ve saç rengi gibi biyolojik özellikler hala kullanılmakta, parmak izi ve retina gibi biyometrik veriler ise kimlik tanımlama ve kimlik doğrulamada öne çıkan alanlar olmaktadır (Beduschi, 2019, s. 2). Dijital kimliğin gelişimi, Google, Bing, Facebook vb. dijital içeriklerin farkında olma ve bireylerin benliğini, benliğin gelişimini ve diğerlerini tamamen sunan içeriklerin süregelen gelişimini kapsamaktadır (Ahlquist, 2016, s. 30). Beduschi; biyometrik pasaportların birçok devlet için standart araçlar olduğunu, biyometrik teknolojisinin Avrupa Birliği'nde de göç yönetimi ve sınır kontrolünde kullanıldığına değinmiștir (Beduschi, 2019, s. 2).

Dünya öncelikle nüfusta gerekliliğin gerçekleşmesi ve birçok ülkenin yaşam alanının geleneksel yarım küresinde bir dönüşüm getiren 4. endüstriyel devrim, Endüstri 4.0 çağına girmiştir. Endüstri 4.0; veri transferinin süresinin azalması, el emeğinin makine emeği ile yer değiştirmesi, finansal kaynakları kaydetme, insan faktörü ve hataları çıkarma yoluyla problemleri çözebilecek, görevleri yerine getirebilecek ve etkinliği artırabilecek bir ağ alanı oluşumuna imkân sağlar (Fedotova, Ushamirskaya, Sigidov, Kuzmina, \& Mandrik, 2020, s. 89). 21.yy'ın ortalarında ve gelecekte toplumumuzun kesinlikle daha yapay zekâya dayalı, büyük veri odaklı ve birbirine bağlı bir dünyada olacağı, sosyal sistemlerin blockchain tabanlı bağlantılar ve dağılmış veri tabanlarının bilgi alt yapısında vurgulanacağı belirtilmiştir (Shibuya, 2020, s. 14). Endüstri 4.0, yapay zekâ, blockchain vb. iletişim teknolojilerinin toplumların yaşamlarını kolaylaştırmakla birlikte, analogdan 
dijitale bir dönüşüm sürecini de beraberinde getirmekte olduğu gözlenmekte, dijital kimliklerin bu anlamda öneminin yakın gelecekte giderek artacağına inanılmaktadır.

$\mathrm{Bu}$ çalıșmada dijital kimlikler ve online iletişim teknolojilerinde yaşanan değişim ve dönüşüm süreçleri ile bir blockchain yeniliği olan dijital kimliklerin ve online iletişim teknolojilerinin insan hayatındaki konumunun ortaya konulması amaçlanmıştır. Çalışmanın literatür taraması kısmında dijital kimlik ve Goffman'ın benlik sunumu kuramı kavramlarına değinilmiştir. Ardından The Circle filmi dijital kimlikler ve Goffman'ın benlik sunumu kuramı bağlamında analiz edilerek yorumlanmıştır. Bu çalışmada The Circle filmi, nitel bir yaklaşımla tematik ve betimsel analiz yöntemiyle ele alınmıştır.

\section{Dijital Kimlik}

Elektronik kimlikler ve doküman doğrulama (eIDV), kullanıcılar ve hizmet sağlayıcılar arasında kimliğin doğruluğuna çözüm getirirken, bir kișinin online hizmetlere erişimi için gerekli kimliğini de tanımlamaktadır (Goode, 2019, s. 5). Uluslararası Telekomünikasyon Birliği (ITU) dijital kimliğin ad, soyad, doğum tarihi, doğum yeri gibi doğumla ilişkili bilgiler, boy, kilo, fiziksel özellikler gibi betimleyici bilgiler, sosyal güvenlik numarası gibi kişisel bilgiler, parmak izi, DNA, retina gibi biyometrik veriler olarak kategorilere bölünebileceğini açıklamıştır (Uluslararası Telekomünikasyon Birliği (ITU), 2018, s. 5). Dijital kimlikler e-mail, metinler, sosyal medya gibi teknolojilerin kullanıcıları tarafından oluşturulmaktadır. Uluslararası Telekomünikasyon Birliği'ne göre dijital kimlikler; kurumsal, fonksiyonel ve işlemsel kimlikler olmak üzere 3 bölümde tanımlanmıştır. Kurumsal dijital kimlikler; doğum kayıtları, evlilik cüzdanı, sosyal güvenlik numaraları gibi belgeleri incelemeye dayanan ulusal kimlik şemalarının bir parçası olarak açıklanmaktadır. Fonksiyonel dijital kimlikler, sigorta, sağlık, taşımacılık gibi özel sektörün ihtiyaçlarını desteklemek için oluşturulurken işlemsel dijital kimlikler birçok sektörde yüz yüze ve online ortamlarda finansal ürünleri veya diğer işlemleri kolaylaştırma amacıyla oluşturulmuştur (Kavut, 2021, s. 534).

1990'ların sonunda online kayıt masrafları sorunları ile başa çıkmak için geniş web hizmetleri ve dijital ekonominin ortaya çıkışı ile vatandaşların bağlantıda oldukları çevreye katılması için dijital kimlikler sağlamak hem işletmeler hem de bireylerin en önemli sorunlarından biri olmuştur. Bu yüzden kimliğin dijital dünyada modern kavramlarını yeniden tanımlayan merkezi, federal, kullanıcı merkezli ve geleneksel olmak üzere dört dijital kimlik modeli açıklanmıștır (El Haddouti \& El Kettani, 2019, s. 2).

Dijital kimlik denildiğinde bir diğer önemli konu ise bu kimliklerin gizlilik ve güvenliğinin sağlanmasıdır. Gizlilik, insan hakkı ve toplumların ilerlemesi için önemli bir ihtiyacıdır. Saygı ve itibar ile insani koşulları sürdürmek için gizlilik bir ihtiyaç olarak görülmektedir (Ayed, 2014, s. 97). Wood ve Smith (Wood \& Smith, 2005, s. 69) bir kişinin dijital kimliğini korumasının yollarını kişisel bilgi paylaşımlarının nasıl yapılacağını garanti altına alma, sosyal güvenlik numaralarını sadece gerektiğini açıklama, hesap makbuzu, sigorta formları, banka hesap bakiyeleri vb. kişisel bilgilerini içeren konuları güvenceye alma, kredi kartı ve kimlik tanımlama bilgilerinin gerçekten gerekli olduğunda paylaşılması olarak açıklamıştır. Dijital kimlik, bir kişinin dijital çağda işlem yapabildiği, tanımlayabildiği araçlardır. Özellikle kanunda yasal, kişisel ve ticari olarak benzersiz bir öneme sahip olan dijital kimliğin 2030'lara kadar yasal kimlik için daha büyük öneme sahip olacağı belirtilmiştir. $\mathrm{Bu}$ anlamda dijital kimliğin hükümetler, özel sektör ve özellikle bireyler için önemi açıktır (Sullivan \& Burger, 2019, s. 235). Dijital kimlikler, bireylerin online platformlardaki kullanıcı adları, şifreleri, doğum tarihleri, sosyal güvenlik numaraları 
gibi biyometrik bilgileri, online arama aktiviteleri, e-nabız, e-sağlık vb. bilgileri, sosyal medya hesapları beğenileri, yorumları, tweetleri, fotoğraf veya video paylaşımları, e-imzalı dilekçeleri gibi bireylerin online dünyada var olmasını sağlamak adına yaptığı veya paylaştığı her şeyi içine alan kapsamlı bir kimlik biçimini ifade etmektedir (Kavut, 2020, s. 996). Tanımlardan ve yapılan araștırma sonuçlarından anlaşıldığı üzere dijital kimliklerin yaşamın birçok alanında kullanım avantajına sahip, eşsiz, tek, bireye özgü, teknoloji destekli ve aynı zamanda bireyin dijital kişiliği ve benlik sunumunu, izlenim yönetimi sürecini de içine alan online bir kimlik türü olduğu dile getirilebilmektedir.

Sosyal medyanın yeni formları çoklu dijital kimlikler paylaşmak ve üretmek için araçlar sağlamaktadır. Ancak sonuçta oluşan kimlik alanı uyumlu bireysel hayat hikâyeleri ve varlıkları hakkında çok az öneride bulunmakta, karmaşık ve dijital kişiliğe dayanan veriler parçalanmıştır. Yeni sosyal medya platformları hem bireylerin kişisel benlik sunularını hem de kontrol etmesi zor olan diğerlerine benliğin yansıtılmasını içine almaktadır (Thomas, 2018, s. 53). Bu noktada Kavut, dijital ortamlarda dijital kimliğin pek çok örneği bulunduğunu ve kartvizitler, sürücü ehliyetleri, banka kartları, kişisel web veya blog sayfalarının bu örnekler içerisinde yer aldığını açıklamıştır (Kavut, 2021, s. 129). Sosyal medya; dijital kimlik ve benlik sunumu açısından önemli bir alan olarak görülebilmekle birlikte dijital kimliklerin bireylerin ehliyet ve pasaportlarından banka kartlarına, CV'lerinden kartvizitlerine varıncaya kadar kapsamlı bir uygulama alanına sahip olduğu gözlenmektedir.

\section{Goffman'ın Benlik Sunumu Kuramı}

Goffman, bireylerin sahne önü ve sahne arkası davranışlarını karşılaştırarak ve örneklendirmek için tiyatroyu kullanarak, bireylerin arzulanan imajlarını göstermek için nasıl performans sergilediklerini ve kişilerarası etkileşimlerini analiz etmiş̦tir (Bullingham \& Vasconcelos, 2012). Goffman, benlik sunumunu hem sahne önü hem de sahne arkası davranışları ile ele almaktadır. Sahne arkası; bireylerin benliklerinin daha az kurgulanmış ve daha az filtrelenmiş halini yansıtırken sahne önü performansları genellikle daha tedbirli ve dikkatli olmaktadır (Smith \& Sanderson, 2015, s. 343). Online sunumlar, sosyal buluşma sitelerinde performans ve online aktivite süreçleri için bireylere ekstra zaman için izin vermektedir. Bu sunumlar Smith ve Watson tarafından arşivlenmiş beden olarak tanımlanır. Online aktiviteler bu arşivlerde oluştuğu için gözetlenebilmektedir (Seehafer, 2017, s. 11). Goffman'ın benlik sunumu kuramında birbirini tanımayan bireylerin birbirlerine kişisel bilgilerini aktararak tanışma ve birbirleri hakkında izlenim edinme imkânı edindikleri açıklanmaktadır (Kavut, 2018, s. 3).

Erving Goffman (Goffman, 2018), benlik sunumu kuramı ile ilgili kavramları Günlük Yaşamda Benliğin Sunumu adlı kitabında Performanslar, Takımlar, Bölgeler ve Bölgesel Davranışlar, Ayrıksı Roller, Karakter Dışı İletişim ve İzlenim Denetimi Sanatı olarak 6 başlık altında açıklamıştır.

Performanslar: Bireylerin gözlemci kitleler önünde sergilediği ve izleyicileri üzerinde etki bıraktığı tüm etkinlikleri, faaliyetleri performans olarak tanımlanmaktadır. Bireylerin performansları sırasında isteyerek veya istemeden yapmış oldukları standart ifade şekilleri vitrin olarak adlandırılmıştır (Goffman, 2018, s. 33). Goffman benlik sunumu olarak bireylerin performanslarını tanımlamıştır. Bu diğerlerinin zihninde özel izlenimler oluşturmak için bireylerin çabaları başka bir deyişle ise izlenim yönetimi anlamına gelmektedir (Tashmin, 2016, s. 90). Goffman performans boyunca aktörün bir kişinin duruşu ve pozisyonu, diştan görünümü (maskeleri), performans boyunca 
sunumu sürdürme, performansı ne kadar anlamış gibi görünmesi, yanlıș sunum olasılığı, bazı durumlarda aldatma ihtiyacı gibi birkaç unsuru dikkate almakta olduğunu belirtmektedir (Koole, 2010, s. 242-243). Goffman'a göre performans anında; bireyler sosyal medya platformlarının yanında yüz yüze iletişimleri boyunca da kabul edilen karakterleri sergilemekten sorumludur. Performanslar, sosyal medya dahil olmak üzere günlük etkileşimler yoluyla bireyler tarafından oluşturulmaktadır. Performanslar favori aktivitelerin tanımlanması, arkadaşları ve ağları tanımlama, profil oluşturma ve değiștirme yoluyla ifade edilebilmektedir (Seehafer, 2017, s. 4-5).

Goffman, kapalı sosyal ortamlarda dört temel bakış açısıyla performansların analiz edilebileceğini ifade etmiştir: (Koole, 2010, s. 243). Teknik boyutu bireylerin kendilerini ifade etme, kendilerini sunma, oluşturma, paylaşma yeteneklerini, politik boyutu; birey ve grupların diğerlerinin davranışlarını kontrol etme, talep etme, onaylama ve uygulama yeteneklerini, yapısal boyutu sosyal bağlantı ve sosyal mesafeleri sinırlayan yatay ve dikey yapıları içerirken kültürel boyutu ise belli bir grup insanın normları, değerleri, gelenekleri, nezaketi, zevkleri, ahlaki değerlerini kapsamaktadır.

Takımlar: Performansların izleyiciler önünde sergilenmesi için iş birliğinde bulunan bireyler grubu performans takımı veya takım olarak tanımlanır (Goffman, 2018, s. 80). Başarılı performanslar genellikle sadece bireyler tarafından değil takım ile sergilenmektedir. Takımlar farklı toplumlar tarafından gözlemlenebilen alanlarda yani sahne önünde performanslarını sergilemektedir (Manning, 1991, s. 75).

Bölgeler ve Bölgesel Davranışlar: Goffman, bölgeyi bireylerin algılarına karşı engellerle çevrilmiş olan yer olarak tanımlarken; performansların sergilendiği yerleri ise vitrin bölgesi olarak adlandırmıștır (Goffman, 2018, s. 107-108).

Ayrıksı Roller: Goffman, performansları sergilerken aktörlerin kullandıkları ayrıksı roller bulunduğunu, bu ayrıksı rollerin gözcü, muhbir, yem, profesyonel müşteri ve aracı olarak gruplara ayrıldığını açıklamıştır (Goffman, 2018, s. 146). Goffman ayrıksı rollerin oyuncu, izleyici ve dışarıdakiler rollerinin dışında olan izleyici veya oyuncuların arasında girerek gizlice bilgilere veya bölgelere erişim sağlayan bireyleri tanımlamak için kullanmaktadır. Takımların sırları ve sırlara erișen diğer kişilerin ayrıcalıkları ile ilgili olmaktadır (Hülür, 2017, s. 162). Gözcü, oyuncular karşısında sıradan bir izleyici gibi davranan, aktörlere öncesinde herhangi bir uyarı ve bildirimde bulunmayan ajanlar olarak tanımlanmıştır. Bir satış görevlisinin müşterilerine nasıl davrandığını gözlemlemek için gerçek müşteri gibi davranan yöneticiler buna örnek gösterilmiștir (Goffman, 2018, s. 143). Muhbir rolündeki kişi takımın bir üyesi gibi görünen, takımla ilgili gizli bilgileri açıkça veya gizlice satan kişilerdir. Bu rolün politika, askeriye, sanayi ve suçlu değişkenleri ünlüdür. Yem rolündeki kişi sıradan bir izleyici gibi hareket eden ancak gerçekte performans sergileyenlerle (aktörlerle) iş birliği içinde olan kişilerdir (Goffman, 1956, s. 90-91). Profesyonel müşteri ayrıksı rolü seyirciler arasında aktörleri izleyen ve ardından performansını izlediği takımın rakibi konumundaki kendi firmasına gördüklerini aktaran kişilerdir. Aracı veya arabulucu ayrıksı rolü ise taraflar arasında daha yakın bir ilişkiyi mümkün kılan araçlar olarak görülmektedir (Goffman, 2018, s. 144). Aynı zamanda performans referans notası olarak tanımlandığında işlevlerine göre performans sergileyenler (aktörler), performans ile hedeflenen kitle (izleyiciler) ve performansta herhangi bir rolü olmayanlar ve dışarıdakiler olmak üzere üç temel rol tanımlanmıştır (Goffman, 2018, s. 140).

Karakter Dışı İletişim: Goffman karakter dışı iletişim kavramını aktörlerin performanslarını sergilerken iddia ettikleri kişilikler yerine kendi öz benliklerini sergilemeleri 
durumunda kurulan etkileşim süreci olarak tanımlamıştır. Bireylerin performanslarını izlenim yönetimi ile sergilemeleri sırasında oynadıkları karakterin içinde kaldıklarını vurgulamıştır (Goffman, 2018, s. 161). Karakter dişı iletişim, aktörlerin etkileşimleri sırasında ses tonunu değiştirme, kaş-göz yaparak anlaşma gibi diğerlerine belli etmeden, resmi izlenimle uyuşmayan davranışları olarak ifade edilir (Hülür, 2017, s. 162-163). Goffman, mevcut olmayana muamele biçimi, sahneleme muhabbeti, takım içi danışıklık, tekrar saflaşma eylemleri olmak üzere dört tür karakter dışı iletişim bulunduğunu belirtmiştir (Goffman, 2018, s. 195).

İzlenim Denetimi Sanatı: Goffman, izlenim denetimi sanatını bireylerin performanslarının aksamamasını sağlayan temel işlevler olarak tanımlamaktadır (Goffman, 2018, s. 196). Goffman, izlenim denetimi sanatını aktörler tarafından performanslarını kurtarmak için başvurdukları savunma nitelikleri, seyirciler ve dışarıdakiler tarafından aktörlerin gösterilerini kurtarmalarına yardımcı olmak için başvurulan savunma nitelikleri ve izleyicilerle dışarıdakilerin aktörler için savunma niteliklerine başvurabilmesi için aktörlerin kullanması gerekli savunma nitelikleri olarak üç türe ayırmıştır (Goffman, 2018, s. 200).

\section{The Circle Filminin Konusu}

The Circle, dünyanın en büyük teknoloji, sosyal medya şirketlerinden biri olarak tanımlanan The Circle'da mahremiyetin olmadı̆̆ı, kullanıcıların birbirlerinin yaşamlarını gözlemleyebildiği, her anın kayıt altına alındığı ve tüm dünyanın kullanıcıları izleyebildiği bir sistemin uygulandığı bir şirketi ve dijital sürecin işleyiş yapısını gösteren bir bilim kurgu filmidir. The Circle filminde sistem içerisinde veri elde etmek ve kullanmak adına sürekli yeni kullanıcılar aranmakta, sisteme yeni kullanıcı ekleyen çalışanlar performanslarına göre başarı elde etmektedir. Azmi, çalışkanlığı ile kısa sürede yöneticilerinin dikkatini çekmeyi başaran filmin başkarakteri Mae Holland, hayalini kurduğu şirkette kısa sürede fark edilerek büyük ve daha önce denenmemiş sosyal bir deney için denek olarak seçilmiştir. Filmin baş karakteri Mae'nin her anını kayıt altına alan, mahremiyetin olmadığı bir çip ile yaşaması istenerek bir deney gerçekleştirilmiştir. $\mathrm{Bu}$ durumun Mae'nin arkadaşlık ve aile ilişkilerinden çalışma yaşamına kadar tüm süreçlerini etkilemekte olduğu, dijital olarak tüm yaşamının herkes tarafından görülebilir, gözlemlenebilir duruma getirmekte olduğu, herkesin herşeyi görebildiği dijital yaşamın olumlu ve olumsuz sonuçları olduğu gözlenmiştir. Filmin sonunda Mae Holland The Circle çalışanlarına yaptığı konuşma esnasında The Circle kurucuları Eamon ve Tom'un kendisi gibi her anlarını diğer kullanıcılarla paylaşabileceği çip kullanmaya davet etmiş ve onların tüm kişisel dosyalarını, maillerini diğerlerine gönderdiğinde kurucuların bu durumdan rahatsız oldukları görülmüştür. Dolayısıyla sistemi oluşturan, bu sistemden kazanç sağlayan kişilerin konu kendilerine geldiğinde mahremiyetlerini korumak istedikleri, şeffaf olamadıkları gözlenmiştir.

Kendisine bir çip verilerek her anı kayıt altına alınmış ve dünyanın her yerinde herkes tarafından görülebilir olmasının insan hayatındaki avantaj ve dezavantajları filmde örnek sahnelerle izleyicilere sunulmuştur. Böyelikle dijital kimliklerin, bireysel online profillerin, sosyal medya platformlarının, internetin, yeni iletişim teknolojilerinin kullanımı noktasında bireylere ve toplumlara kişisel özgürlük, mahremiyet, etik, dijital farkındalık, dijital iletişim, online ilişkiler konularında sosyal mesajlar verilmek istendiği gözlemlenmiştir. 


\section{Amaç, Yöntem ve Örneklem}

$\mathrm{Bu}$ çalıșmada dijital kimlikler ve online iletişim teknolojilerinde yaşanan değişim ve dönüşüm süreçleri ile bir blockchain yeniliği olan dijital kimliklerin ve online iletişim teknolojilerinin insan hayatındaki konumunun ortaya konulması amaçlanmıştır. Bu çalışmada dijital kimlikler, benlik sunumları, online iletişim teknolojileri konularıyla ilişkili olan bir bilim kurgu filmi üzerinden dijital kimlikler ve online iletişim teknolojilerinin insanların yaşamlarına olan etkileri, online iletişim teknolojileri ile yaşanan değişim ve dönüşüm süreçleri gösterilmek istenmiştir. Dijital kimlik konusunun yeni ve güncel bir konu olması göz önünde bulundurularak, online iletişim teknolojileri ve dijital kimliklerin hayata ne türden çözümler getirdiği, avantajları ve dezavantajları aktarılarak, online iletişim teknolojilerinin kullanımında kullanıcılara yeni bir bakışı sunulmaktadır. The Circle filmi, dünyanın en büyük, güçlü teknoloji ve sosyal medya şirketi olarak tanımlanan The Circle'da bireysel online profillere, dijital kimliklere sahip olan bireylerin yaşamlarının incelenmesi ve kullanıcılarının yaşamlarını mahremiyet, etik ve kişisel özgürlükler, sınırlar kavramları olmadan her anlarını bu platform içerisinde paylaşmaları üzerine kurgulanmış bir bilimkurgu filmidir. Amaçlı örnekleme yöntemiyle The Circle filminin seçilmesinin nedeni; filmin dijital kimlikler kavramına ve Goffman'ın benlik sunumu kuramı ve alt başlıklarına uygun olarak dijital kimlikler, tiyatro, oyun, karakter, aktör, roller, takımlar, bölgeler ve bölgesel davranışlar, ayrıksı roller, karakter dışı iletişim, izlenim denetimi sanatı, sahne önü ve sahne arkası konularında analiz için zengin bir içerik ve altyapı sunmasıdır. Bu bağlamda filmde, sosyolojik ve psikolojik kavramlardan yararlanılarak, dijital kimlik ve online iletişim teknolojileri ile değișen süreçler örneklerle aktarılmıştır. Film ile sosyal medyanın, dijital teknolojilerin, dijital iletişimin insanların yaşamını nasıl etkilediğinin mahremiyet, gözetim toplumu, dijital kimlikler, benlik sunumları kavramları perspektifinde yansıtıldığı görülmüştür.

\section{Goffman'ın Benlik Sunumu Kuramı Bağlamında The Circle Film Analizi}

Bu bölümde The Circle filmi Goffman'ın benlik sunumu kuramı kavramları doğrultusunda incelenmiștir. Dijital kimlikler, Goffman'ın benlik sunumu kuramı ve The Circle filmi bu araştırmanın sınırlılığıdır. Araştırmanın kuramsal çerçevesinde dijital kimlik kavramı ve Goffman'ın benlik sunumu kuramı kullanılmıștır. Araştırmanın analizi sürecinde film analizi yönteminden yararlanılmıştır.

Goffman'a göre sosyal etkileşim, her oyuncunun çeşitli rollerinin bulunduğu bir sahnede insanların günlük yaşamlarını sürdürmesine ve tiyatroya benzetilebilmektedir. Tiyatro performansları gibi sosyal etkileşimler aktörlerin izleyicilerin içinde sahnede olduğu sahne önünde (ön bölge) yer almaktadır. Bireylerin diğerlerinin önünde oynadıkları rollerden ve kimliklerden kurtuldukları ve kendileri olabildikleri alan sahne arkası (arka bölge) olarak tanımlanmıştır (Tashmin, 2016, s. 91).

Tablo 1. Goffman'ın Benlik Sunumu Kuramına Göre The Circle Analizi

\begin{tabular}{|l|l|}
\hline Tiyatro & The Circle \\
\hline Oyun & Sosyal ağ etkileşimleri \\
\hline Karakter & Gerçek Sen Dijital kimlik sistemi ve The Circle kullanıcıları \\
\hline Aktör & Mae Holland \\
\hline Rol & Sosyal medya davranışları, etkileşim şekilleri \\
\hline İzleyici & The Circle ve Mae'nin takipçileri \\
\hline Sahne Önü & Mae'nin sensör ve çip takılıyken yapmış olduğu davranışlar \\
\hline Sahne Arkası & Mae'nin sensör ve çip olmadan yapmış olduğu davranışlar \\
\hline
\end{tabular}


Performanslar: Filmde, teknoloji devi The Circle şirketinde çalışmaya başlayan Mae Holland karakteri ve onun sosyal medya ve online iletişim teknolojilerini kullanmasının bir insanın yaşamı üzerindeki etkileri değerlendirilmiștir.

Öncelikle şirketin kurucularından Eamon Bailey'in Seechange adını verdikleri her yere kamera yerleștirerek herşeyin görülüp izlenebileceği bir teknolojiden tüm çalışanlarının yer aldığı bir toplantıda söz ettiği ve uygulamanın tanıtımını gerçekleştirdiği görülmüştür.

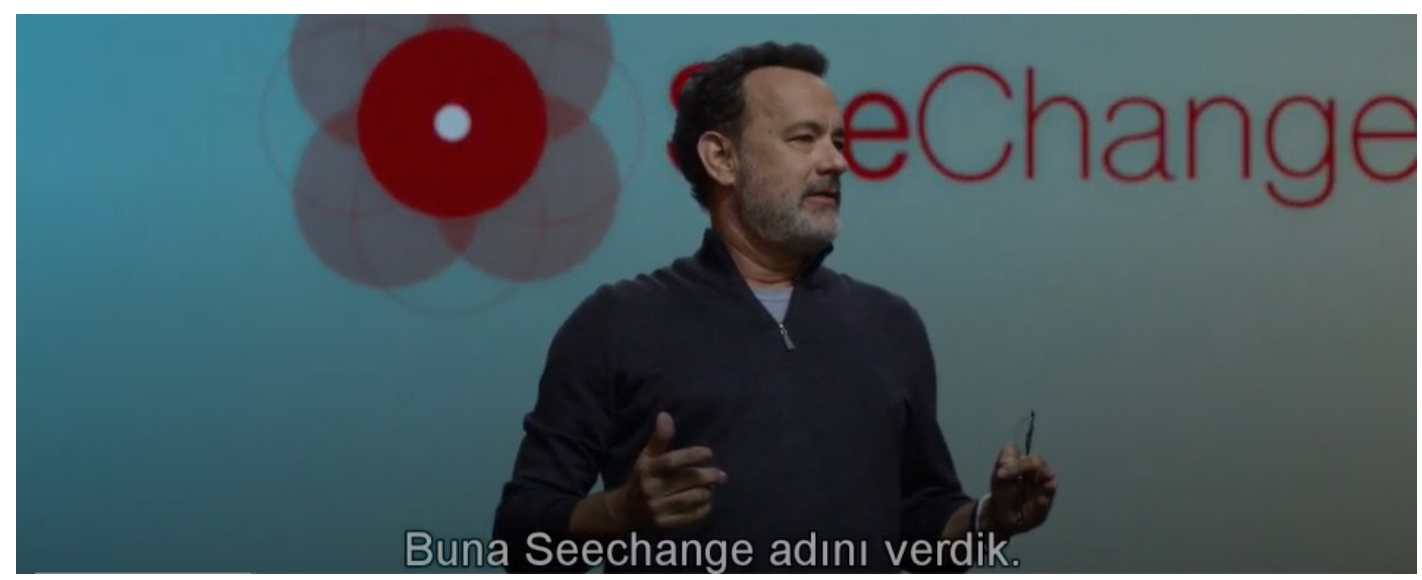

Görsel 1. Seechange Tanıtımı (17:27)

Uygulamanın tanıtımı esnasında Eamon Bailey: "Herşeyi görüp duyacağız, bir şeyi oluyorsa bileceğiz. Buna Seechange adını verdik. Seechange. Bilmek güzeldir. Fakat herșeyi bilmek daha da güzel.” şeklinde açıklamada bulunmasıyla dijital teknolojilerin, kameraların, izlenebilirliğin, şeffaflığın insanların hayatındaki etkilerine yer verildiği görülmüştür.

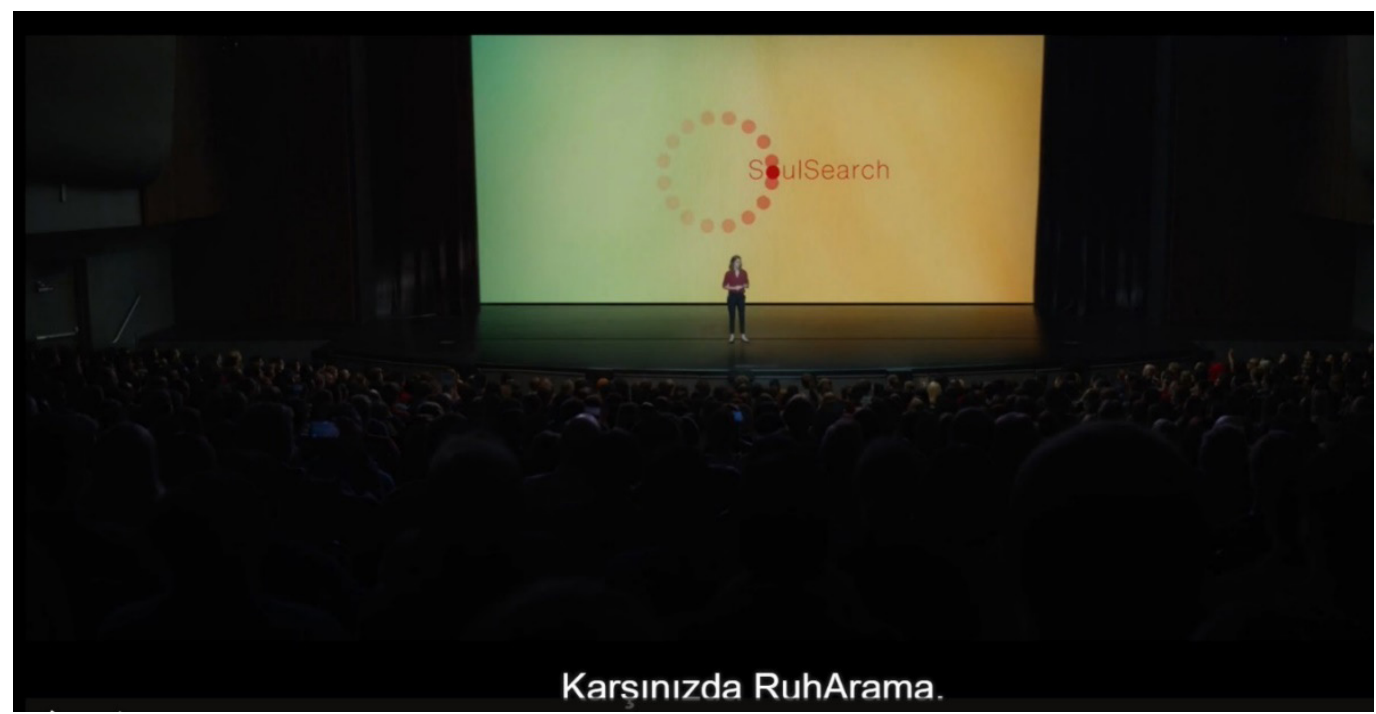

Görsel 2. The Circle Filmi SoulSearch-Ruh Arama Teknolojisi Tanıtımı Sahnesi (1:15)

Performansı sergileyen baş aktör Mae'dir. Mae'nin tüm The Circle çalışanlarına ve onları izleyenlere tanıttığı "Soul Search-Ruh Arama" teknolojisi ile 20 dakika içinde istenilen herhangi bir arkadaşın ya da kanun kaçağının bulunabilmesi sahnesi performans ve vitrin kavramlarına örnek gösterilebilmektedir. Canlı olarak yapılan çalışma ile ise sadece 10 dakika içinde kanun kaçağı bulunmuştur. Bu durumun gerçekte de sağlanması halinde kaçak olan, gizli olan veya sır olan her şeyin online teknolojiler sayesinde bulunabileceğini, gelecekte her şeyin şeffaflaşacağını, mahremiyet kavramının ise olmayacağı bir döneme geçileceğini düşündürebilmektedir. 
Takımlar: The Circle şirketinde hem müşteriler ile iletişimde hem de alınan kararlarda bir takım olarak çalışıldığı görülmektedir. Filmde The Circle şirketinin sahibi Eamon Bailey tarafından The Circle ve GerçekSen sistemlerinin tanıtımı yapılırken Eamon'un “GerçekSen'de profil oluşturmak için gerçek adresi olan, gerçek biri olmanız gerek. Kişisel bilgileriniz, gerçek sosyal güvenlik numaranız olacak" sözleri dijital kimlik tanımını akla getirmektedir. Aynı zamanda The Circle takımı olarak sistem üzerine çalışmaları gösterilmiştir. Nitekim Goffman'a göre takım; performansları sergilerken işbirliğinde bulunan bireylerden oluşmaktadır.

Bölgeler ve Bölgesel Davranışlar: Filmde Mae'nin The Circle'da ilk çalışmaya başladığı zamanlarda sosyal medyayı kullanmayan, The Circle çalışanları tarafından sosyal medya hesabı açması ve aktif kullanması için teşvik edilen, gizemli bulunan bir karakter olduğu görülmüştür. Sosyal medyadan ve iletişim teknolojilerinden faydalanmaya başlayan Mae, ilk zamanlarda mutlu bir birey iken filmin sonlarına doğru kendisinin șeffaf olarak tüm yaşamını bir çiple geçirmeye karar vermesi ve tüm anını herkese açık olarak paylaşması, babasının rahatsızlığından dolayı ailesine de aynı çiplerin verilmiş olması ve ailesinin en özel anlarının deşifre olması, arkadaşının yaptığı bir tasarımı olumsuz sonuçları olabileceğini düşünmeden paylaşmasının ardından arkadaşının ciddi sorunlar ve sıkıntılarla yüzleşmek zorunda kalması nedenleriyle zamanla davranışlarını ve yaklaşımını değiştirmesine neden olduğu görülmüştür. Nitekim Soul Search-Ruh Arama özelliği gibi yıllardır görüşmediği arkadaşına saniyeler içinde ulaşması ancak arkadaşının kameralar önünde yer almamak için kaçarken ölmesi gibi pek çok etken ile iletişim teknolojilerinin ve dijitalin olumsuz tarafları da aktarılmıştır. Bu yönleriyle de filmde dijital teknolojilerin kullanımının hayata sağladığı kolaylıklar yanında, ölçülü kullanımın, mahremiyetin önemi, gözetim olgusu kavramlarına da yer verilmiştir. Bireylerin davranışlarını sergilerken bölgelere göre farklılıklar bulunduğu da görülmektedir. The Circle içindeki dünya ve Mae'nin ailesinin, arkadaşlarının yaşadığı küçük bir bölge arasındaki kültürel, teknolojik, sosyal gelişmelerdeki farklılıkların ve hayata bakış açılarının bölgesel olarak davranışlarına yansıdığı görülmektedir.

\section{Ayrıksı Roller:}

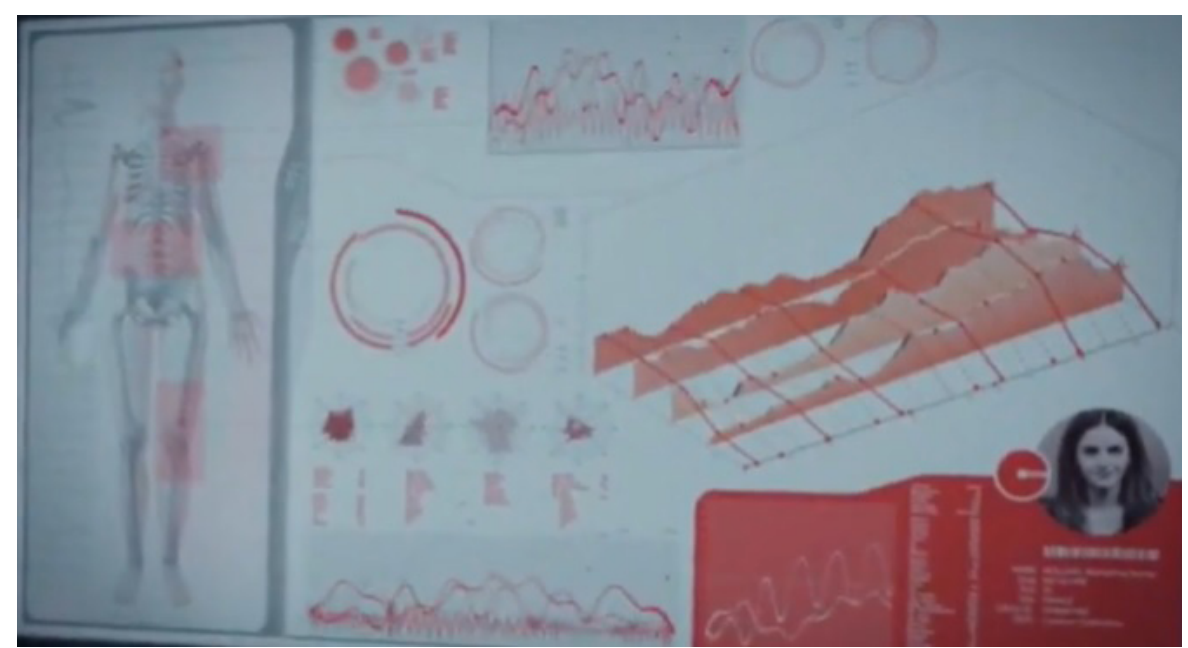

Görsel 3. The Circle Sensör Teknolojisi ve Tıbbi Alım Sahnesi (35:59)

Görsel 3'de görüldüğü üzere; Mae'nin sağlık odasında kendisine verilen sensörü içmesi ve doktorun Mae'nin bileğine medya bandını takmasının ardından yapılan eşleşme ile kalp atışları, kan basıncı, uyku düzeni, uyku verimi, uyku kalitesi, nabzı, kolesterol 
bilgisi, sindirim etkinliği gibi konular hakkında tüm veriler toplanmıştır. Tüm verilerin ise tablette, bulut sisteminde toplandığı belirtilmiștir. Günümüzde de bu tarz bir örneği e-nabız sisteminde görebildiğimiz düşünülmektedir. Dolayısıyla dijital kimlikler hayatımızın içinde yer almaya başlamış durumda, giderek kullanımının ve hayatımızdaki yerinin artacağı öngörülmektedir. Sensörler, Goffman'ın ayrıksı roller içerisinde tanımladığı gözcü kavramı ile ilişkilendirilebilmektedir.

Mae ve Circle'daki GerçekSen uygulamasını icat eden Ty Lafitte The Circle'daki her șeyin kayıt altına alındığı ve izlendiği yasak odaya girdiklerinde "Ty: Amaç her şeyin kaydedilip, izlenip, yayınlanıp, saklanıp, incelenip her açıdan The Circle için hazır olması. Sağlık kaydın yapıldı mı? Mae: Evet. Ty: Bak. Her adım, her nefes, hepsi saklanıyor. Istedikleri gibi kullanabilirler. Araştırılıyoruz." sözleri ise online teknolojilerin ve kimliğin her platformda şeffaf bir biçimde tanımlanmasının olumlu olduğu kadar olumsuz taraflarının da olacağını, mahremiyetin kalmayabileceğini işaret etmektedir. Bu duruma örnek olarak sosyal medya profil bilgilerinin sosyal medya sahiplerinin kullanıcı bilgilerini markalar ile paylaşması Facebook vb. platformlarda yaşanan olaylar gösterilebilmektedir. Goffman'ın ayrıksı rollerinden muhbir rolünü akla getirmektedir.

Bir diğer muhbir ayrıksı rolü ise The Circle sisteminin kurucusu Ty Lafitte'nin filmin başkarakteri Mae Holland'a Circle'daki “Cemberdeki herkesin bilgileri araştırılıyor, üzerinden para kazanıllyor, herkesin verileri inceleniyor, paraya çevriliyor" ifadesi ile örnek gösterilebilmektedir. Goffman, muhbir ayrıksı rolünü takım üyesi gibi davranan ancak üyesi olmayan, takımın bilgilerini satan kişi veya kişiler için kullanmaktadır. Bu olayda da verilerin gizlice başkalarına satılması nedeniyle muhbir ayrıksı rolü ile ilişkilendirilmiștir. Görselde de görüldügü üzere; The Circle sisteminin kurucusu olan Ty Lafitte ve Mae'nin yasak bölge (restricted area) olarak tanımlanan alandaki konuşmaları sonucunda; tüm The Circle kullanıcılarının verilerinin saklı tutulduğu, depolandığı, arşivlendiği ve verilerin incelenerek kullanıldığı, verilerin sermayeye dönüștürüldügü, paraya çevrildiğinin dile getirildiği gözlenmiştir. Günümüzde de sosyal medya uygulamaları, uygulama kullanıcılarının bireysel profilleri, profil paylaşımları ve elde edilen verilerin bu uygulamaların sahipleri tarafından markalar ile iş birliği yapılarak kișisel sermayeye ve finansal kazanç alanına dönüştürülmesi örnek gösterilebilmektedir. Bu noktada tüm sosyal medya kullanıcılarının dijital kimlik kullanımlarında dijital etiğe, mahremiyet koşullarına dikkate ederek paylaşımda bulunmasının önem arz ettiği görülebilmektedir.

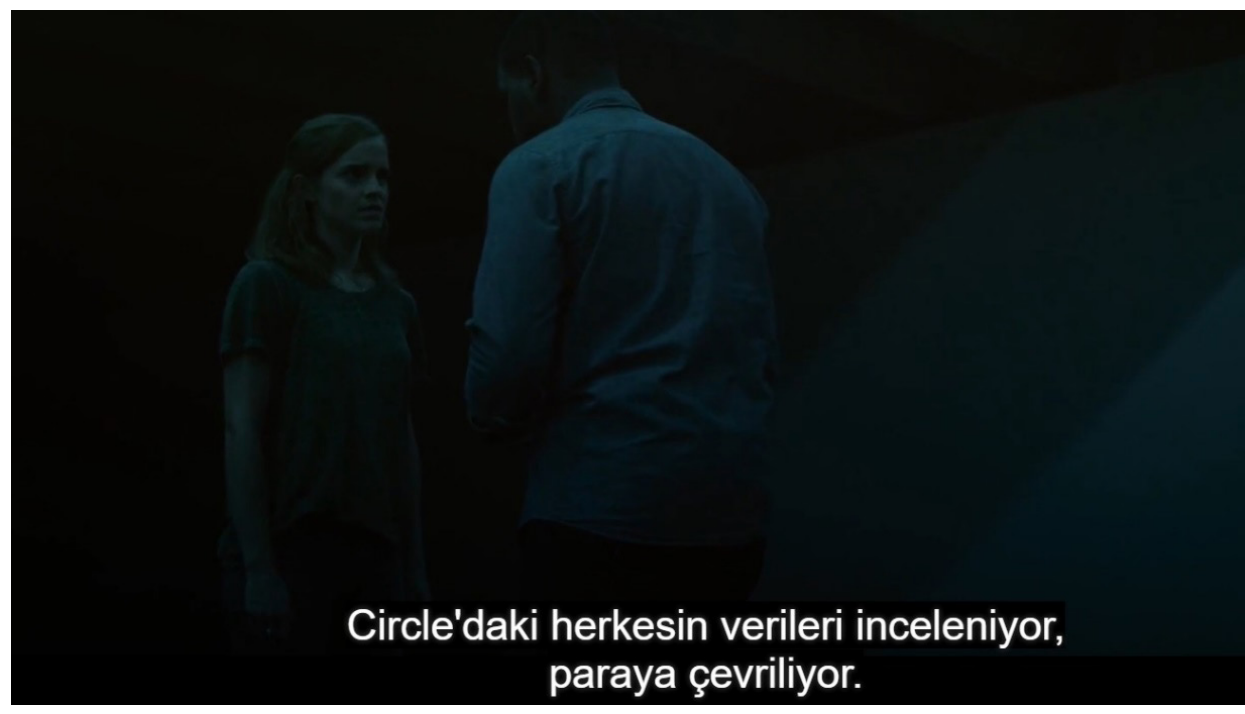

Görsel 4. The Circle Sistem Kurucusu ve Mae- Yasak Bölge Sahnesi (43:40) 
Karakter Dışı İletişim: Filmin asıl aktörü ve performanslarını vitrin önünde sergileyen karakteri Mae'nin hayalini kurduğu ve çalışmaya başladığı The Circle şirketine girdikten sonra yaşamış olduğu tavır ve davranış değişiklikleri Goffman'ın karakter dışı iletişim kavramı ile açıklanabilmektedir. Bu anlamda Goffman karakter dişı iletişimi bireylerin öz benliği ile davranışlar sergilemesi, oynadıkları karakterin dışına çıkabilmesi olarak tanımladığı dikkate alındığında; Mae'nin filmin başından son anlara kadar karakterin içinde kaldığı, son anlarda farkına varmaya başladığı ve karakter dışı iletişim sergilediği görülmüştür.

En yakın arkadaşı Mercer'in vefatından sonra The Circle'da yaptığı konuşma karakter dışı iletişim örneğini olarak gösterilebilmektedir.

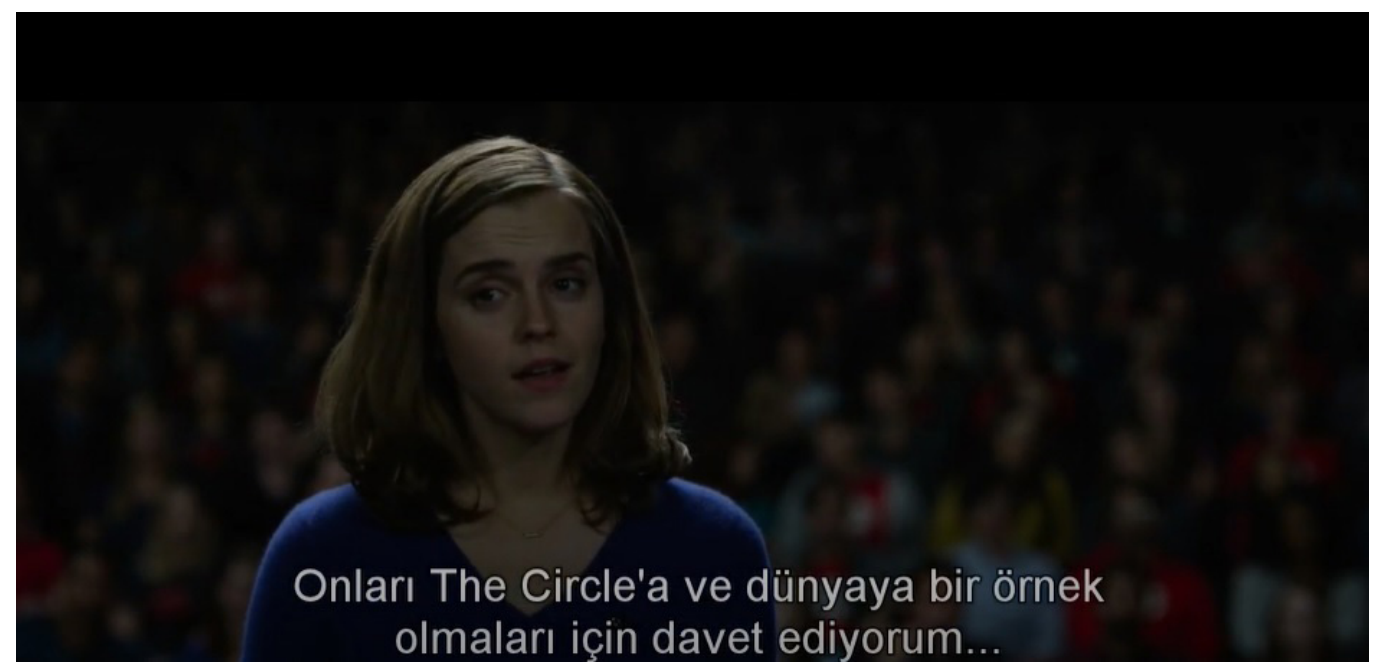

Görsel 5. Mae'den Yöneticilerine Şeffaf Olma Daveti Sahnesi (1:37:40)

"Mae: Kendim ve The Circle hakkında bir șeyin farkına vardım. O da şu, kopmak istemiyorum. Ailem, dostlarım ve değer verdiklerim için araștırma yapmak istemiyorum. Mercer'in izini kaybettik? Peki ya birbirimizle hep bağlantıda kalsaydık? Araştırmak yerine hep bilseydik? Bahsettiğim şey radikal açıklık ve kopmayan bağlantı. Dijital dünyanın ikiyüzlülüğünün farkındasınız. Herșeyi bulut sisteminde istiyoruz ama liderlerimiz bunun üzerinde. Bu yüzden Eamon ve Tom'u öncülük ettikleri bu deneyde bana katılmaları için davet ediyorum. Şeffaf olmaya" diyerek sistem yöneticilerinin de șeffaf olması gerektiğini ifade ettiği, ardından Eamon ve Tom'un tüm mail hesapları ve yazışmalarını tüm The Circle kullanıcıları ile paylaştığı görülmüştür. Bu sahnede Mae'nin davranışı kendi öz benliği ve farkındalık düzeyinin artmasının ardından gerçekleştirdiği bir eylem olması nedeniyle karakter dışı iletişim olarak tanımlanabilmektedir.

İzlenim Denetimi Sanatı: Mae The Circle'a geldiğinde Annie ile asansöre bindiğinde teknoloji şirketi The Circle'daki farklılık ve yeniliklerle karşılaşmaya başlamaktadır. "Mae: Nasıl yani? Annie: Herșey sensörler sayesinde. Asansör kimliğini okuyup sana Merhaba diyor. Bunu genellikle ziyaretçilere yapıyoruz. Genelde etkileniyorlar" şeklinde geçen konuşma ve ekrana kendi fotoğraflarının yansıması ile kimliklerin ve online teknolojilerin gücü görülebilmektedir. 


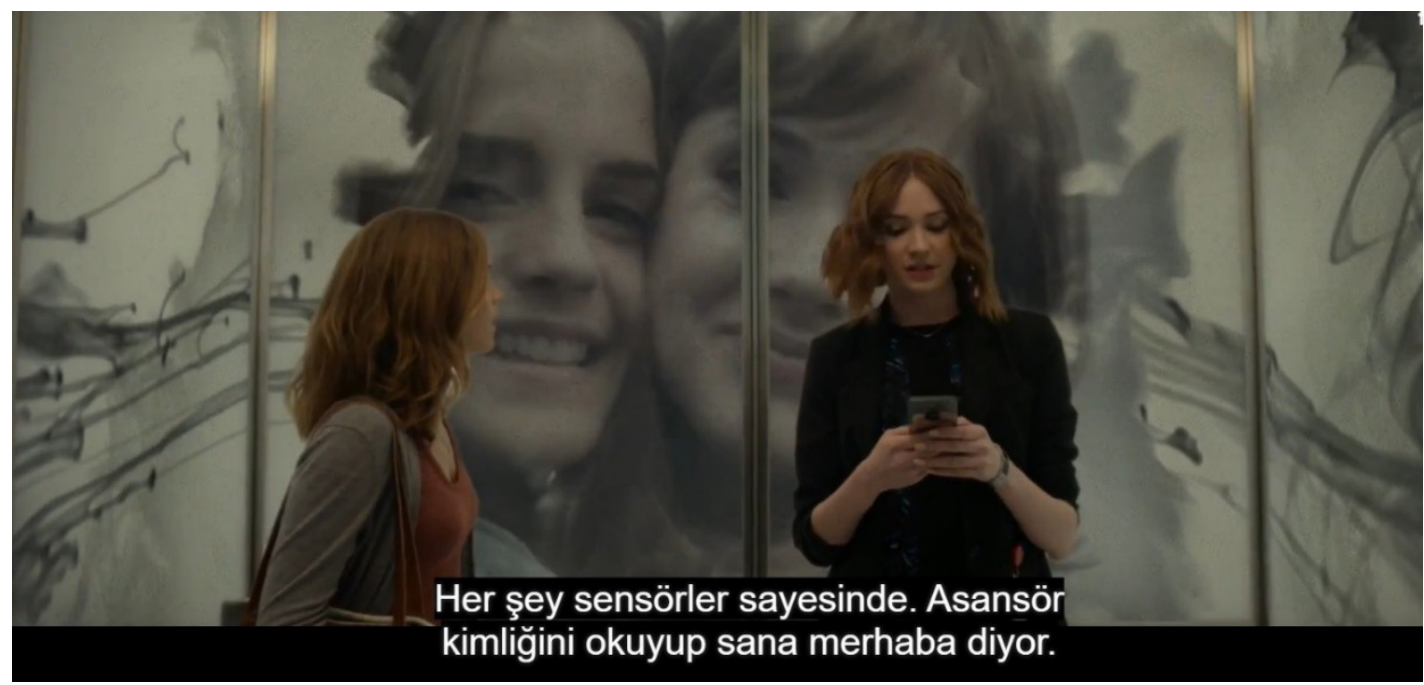

Görsel 6. Asansör Kimlik Okuma Sahnesi (09:05)

Asansör kimlik okuma sahnesinin izlenim denetimi sanatı için bir örnek olarak sunulduğu gözlenmiştir. Ekrana asansöre binen bireylerin görsellerini yansitarak, The Circle teknoloji şirketine gelen bireyleri etkilemek adına sensörler aracılığıyla bir uygulama tanıtıldı̆̆ı ifade edilmiştir. Asansörün sensörler sayesinde binen kişileri tanıyabildiği ve fotoğraflarını ekrana yansıtarak Merhaba dediği belirtilmiştir. Görselde görülen sahnede de şirkete ilk kez gelen Mae'i etkilemek adına bu şekilde bir aktarım yapıldığı görülmüştür. İzlenim denetimi açısından Mae'nin beden dili incelendiğinde; şaşkınlığı ve etkilendiği görülebilmekte, diğer ziyaretçilerin de bu durumdan etkileneceği düşünülmektedir.

Mae'nin filmde toplantı esnasında "Neden her şeyi tek bir sistem haline getirmiyoruz? Verginizi ödeyebilirsiniz, oy kullanabilirsiniz, park cezanızı ödeyebilirsiniz? Hepsini The Circle hesabınızdan yapabilirsiniz. Kullanıcları yüzlerce saatlik eziyetten kurtarıp, hükümete milyarlar tasarruf ettirebiliriz" cümleleri tek bir dijital kimlik alt yapısı oluşturulmasının ve bu alt yapı ile insanların hayatları için gerekli tüm işlemleri online olarak yapabilmesinin mümkün kılınabileceği açıklanmıştır. Sonuç olarak, kullanılan teknolojiler ile hedef kitleleri üzerinde bir izlenim denetimi sanatı oluşturulduğu görülmektedir.

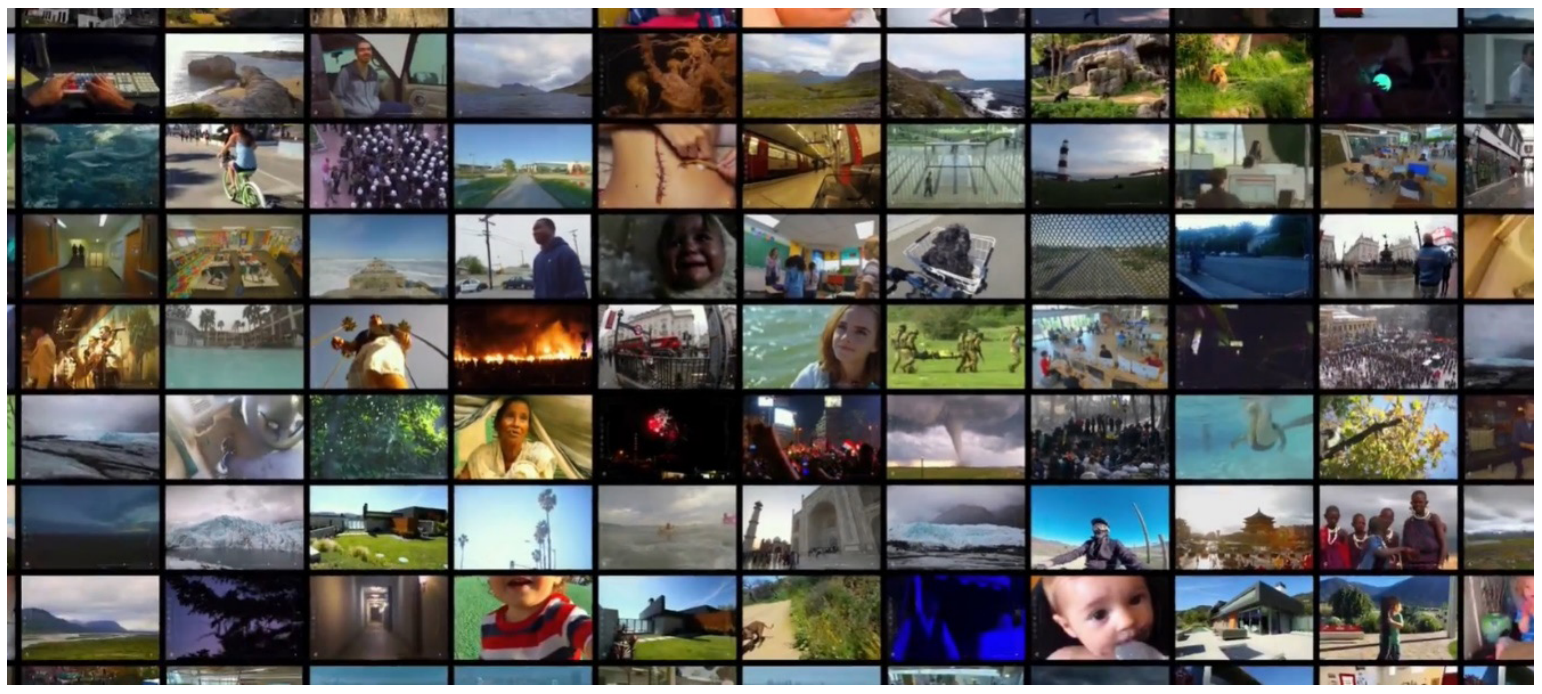

Görsel 7. The Circle Filmi Son Karesi (1:41:30) 
Filmin son karesinde herkesin kamera ekranından görülmesi, film ile gelecekte herkesin herkesi görebildiği ve izleyebildiği bir düzen olacağına ilișkin bir vurgu yapılmak istendiği düşünülmektedir. Herkesin herkesi gözetlediği bir sistem olan Omniptikon kavramını da akla getirmektedir. Omniptikon ise Jeffrey Rosen tarafından ortaya çıkarılan herkesin, her an ve her yerde gözetim altında olmasını tanımlamaktadır (Sprague, 2007, s. 2). Gözetimden bir süre sonra rahatsız olunduğu ve çoğunluğun Mae'i bir çip sayesinde izlediği bir sistem alt yapısı mevcut olduğu için Sinoptikon kavramını da içine almaktadır. Sinoptikon kavramı ise ilk kez 1997'de Thomas Mathiesen tarafından ortaya çıkarılan azınlığın çoğunluğu izlediği bir gözetim sistemidir (Hıdıroğlu, 2019, s. 1413). Sinoptikon ve omniptikon gözetim sistemlerinin rıaya dayalı ve gönüllü olarak haz ve eğlence kurgusu ile gerçekleştirilen sosyal medyanın da örnek alan olarak gösterildiği bir yapısı olduğu düşünüldügünde; The Circle sisteminin de eğlence, haz, arkadaşlık temaları üzerinden benzer bir yaklașıma sahip olduğu ifade edilebilmektedir.

\section{Sonuç}

Dijital teknolojiler hayatımızın kaçınılmaz bir parçası durumundadır. Online teknolojilere direnç gösteren az bir kitle ile birlikte çoğunluğun bu teknolojiden memnun olduğu, hayatının her alanına entegre ettiği ve faydalandığı düşünülmektedir. Özellikle koronavirüs pandemisinin ardından tüm dünyanın online sürece yoğunlaştığı ve gelecek dönemde de dijitale ilişkin tüm iletişim süreçlerinin ve alt yapılarının analog iletişimden önce geleceği öngörülmektedir. Bu makalenin amacı dijital kimlikler ve online iletişim teknolojileriyle yaşanan değişim ve dönüşüm süreçlerini, dijital kimliklerin ve online iletişim teknolojilerinin insanların hayatındaki konumunu, benlik sunumlarını Goffman'ın benlik sunumu kuramı bağlamında The Circle filminden örnekler ile ortaya koymaktır.

Filmde baş karakter Mae Holland'ın The Circle şirketine girdikten sonra çeşitli performanslar sergilediği, The Circle'daki yaşamının Goffman'ın sahne önü kavramına, ailesi ve arkadaşları ile geçirdiği zamanlar, çip olmadan yaptığı davranışlar ve konuşmaların ise sahne arkası kavramına karşılık geldiği görülmüştür. Mae'nin ailesinin ve arkadaşlarının yaşadıkları bölge ile The Circle şirketi içerisindeki dünyanın farklı olduğu, Goffman'ın bölgeler ve bölgesel davranışlar kavramına uyumlu olduğu gözlenmiștir.

Film içerisinde yaşanan performans ve vitrinlerde sahne önünde Goffman'ın ayrıksı rollerinden muhbir, gözcü ve profesyonel müşteri rollerine yer verildiği görülmüștür. Aynı zamanda The Circle teknoloji şirketinin teknoloji üstünlükleri, sağlanan avantajlar vb. ile The Circle takipçileri için izlenim denetimi sanatı oluşturulduğu görülmüştür. Filmde son karede kameralar önünde farklı șehirler, farklı kültürler ve insanların verilmesi ile herkesin herkesi görebileceği, şeffaflığın ön plana çıktığı, mahremiyetin azaldığı, sahne önü ve sahne arkası davranışlarının birbirinden farklılık gösterdiği, benlik sunumlarının, gösteri toplumunun ön plana çıktığı bir dijital dünyanın yakın gelecekte var olacağına ilişkin sinyallere işaret edilmek istendiği ileri sürülebilmektedir.

Film genel olarak değerlendirildiğinde; dijital teknolojilerin ve sosyal medyanın belirli oranlarda kullanılması gerektiği, şeffaflığın önemli olduğu ancak mahremiyetin ve belirli kişisel alan sınırlarının korunmasının kritik önem teşkil ettiği görülebilmektedir. The Circle filminin diğer teknoloji tabanlı yapımlardan farklı olarak teknolojinin sadece olumlu veya sadece olumsuz yanlarını aktarmayıp hayatın içerisinde hem olumlu hem de olumsuz pekçok olay ve duruma sebep olabileceğinin örnek sahnelerle net bir biçimde vurgulandığı, bu örneklerin Facebook, Google ve Apple gibi teknoloji şirketlerinin günlük yaşam pratikleri ile benzerlik gösterdiği ifade edilebilmektedir. 
Sonuç olarak, The Circle filmi analiz edildiğinde Goffman'ın performans, vitrin, takımlar, bölgeler ve bölgesel davranışlar, ayrıksı rollerden muhbir, gözcü ve profesyonel müșteri rolleri, karakter dıșı iletișim, izlenim denetimi sanatı kavramlarına ilișkin örnekler bulunmuştur. Bu makalenin dijital kimlik ve dijital farkındalık, dijital iletişim, online ve sanal ortamlar, izlenim yönetimi, sahne önü ve sahne arkası davranışlar, benlik sunumları bağlamında yapılacak çalışmalara katkı sunacağına inanılmaktadır.

\section{Kaynakça}

Ahlquist, J. (2016). The Digital Identity of Student Affairs Professionals . J. A. E.T Cabellon içinde, New Directions for Student Services (Cilt 155, s. 29-46).

Al-Khouri, M. (2014). Digital Identity: Transforming GCC economies. Innovation: Management, Policy \& Practice , 16(2), 184-194.

Alves, T., Natalio, J., Henriques-Calado, J., \& Gama, S. (2019). Incorporating Personality in User Interface Design: A Review. Personality and Individual Differences, 1-14. doi: https://doi.org/10.1016/j.paid.2019.109709

Ayed, B. G. (2014). Privacy and Digital Identity . Architecting User-Centric Privacy-as-aSet-of-Services, 97-120. doi:10.1007/978-3-319-08231-8_4.

Beduschi, A. (2019). Digital Identity: Contemporary Challenges for Data Protection, Privacy and Non-Discrimination Rights,. Big Data\&Society, 1-6.

Bouncken, R., \& Barwinski, R. (2020). Shared Digital Identity and Rich Knowledge Ties In Global 3D Printing - A Drizzle In The Clouds? Global Strategy Journal.

Bullingham, L., \& Vasconcelos, A. (2012). The Presentation of Self in The Online World': Goffman And The Study of Online Identities . Journal of Information Science.

El Haddouti, S., \& El Kettani, M. E.-C. (2019). Analysis of identity management systems using blockchain technology. In 2019 International Conference on Adavanced Communication Technologies and Networking (CommNet) (s. 1-7). IEEE.

Fedotova, V., Ushamirskaya, F., Sigidov, U., Kuzmina, I., \& Mandrik, V. (2020). Industry 4.0 as a New Vector of Growth and Development of the Knowledge Economy, Artificial Intelligence: Antropogenic Nature vs. Social Origin,. E. G. B. içinde, Advance in Intelligent Systems and Computing AISC 1100 (s. 88-97). doi:https:// doi.org/10.1007/978-3-030-39319-9_9.

Gallager, G. R. (2008). Principle of Digital Communication. Cambridge University Press.

Glaser, F., Hawlitschek, F., \& Notheisen, B. (2019). Blockchain as a Platform. H. Treiblmaier, \& R. B. (Ed.) içinde, Business Transformation Through Blockchain Volume II, (s. 121-144). Palgrave Macmillan.

Goffman, E. (1956). The Presentation of Self in Everyday Life. Edinburgh.: University of Edinburgh Social Sciences Research Centre.

Goffman, E. (2018). Günlük Yaşamda Benliğin Sunumu (2.bsk b.). (B. Cezar, Çev.) İstanbul: Metis Yayınları.

Goode, A. (2019). Digital Identity: Solving The Problem of Trust. Biometric Technology Today, 5-8.

Hıdıroğlu, İ. (2019). Ana-Akım Filmlerde Gözetim Olgusunun Temsili . Atatürk Üniversitesi Sosyal Bilimler Enstitüsü Dergisi, 23(3), 1407-1426. doi:https://doi. org/10.1007/978-3-319-92901-9_2. 
Hülür, A. (2017). Erving Goffman: Günlük Yaşamda Benliğin Sunumu . Abant Kültürel Araştırmalar Dergisi, 2(4), 158-165.

Kavut, S. (2018). Goffman'ın Benlik Sunumu Kuramı Bağlamında Sosyal Medyada Kimlik İnşası: Instagram Üzerine Bir Araştırma. Nosyon: Uluslararası Toplum ve Kültür Çalışmaları Dergisi, 1(1), 1-12.

Kavut, S. (2020). Kimliğin Dönüşümü: Dijital Kimlikler. Selçuk İletişim Dergisi, 13(2), $987-$ 1008. doi:10.18094/JOSC.691445

Kavut, S. (2021). Digital Identities in the context of Blockchain and Artificial Intelligence. Selçuk İletişim Dergisi, 14(2), 529-548.

Kavut, S. (2021). Eleştirel Söylem Analizi Bağlamında Haber Sitelerinde Dijital Kimlik Başlıklı Haberlerin İncelenmesi. Uluslararası Kültürel ve Sosyal Araştırmalar Dergisi, 7(1), 127-138.

Koole, M. (2010). The Web of Identity: Selfhood and Belonging in Online Learning Networks. H. V. Dirckinck-Holmfeld L içinde, Proceedings of the 7th International Conference on Networked Learning 2010.

Manning, P. (1991). Drama as Life: The Significance of Goffman's Changing Use of the Theatrical Metaphor . Sociological Theory, 9(1), 70-86.

Olivera, A. M., Bertolino, A., Dominguez-Mayo, J., Jose-Escalona, M., \& Matteucci, I. (2020). Digital Persona Portrayal: Identifying Pluridentity Vulnerabilities in Digital Life. Journal of Information Security and Applications, 52, 1-15.

Seehafer, M. D. (2017). \#Nofilter: Exploration of Instagram and Individuals' Conception of Self. North Dakota State University of Agriculture and Applied Science, Master Thesis.

Shibuya, K. (2020). Digital Transformation of Identity in the Age of Artificial Intelligence. Springer. .

Smith, R., \& Sanderson, J. (2015). I'm Going to Instagram It! An Analysis of Athlete SelfPresentation on Instagram . Journal of Broadcasting \& Electronic Media, 342-358. doi:10.1080/08838151.2015.1029125.

Sprague, R. D. (2007). From Taylorism to the Omnipticon: Expanding Employee Surveillance Beyond the Workplace. 25 J. Marshall J. Computer \& Info. L. 1, 1-36.

Sullivan, C., \& Burger, E. (2019). Blockchain, Digital Identity, E-government. H. Treiblmaier, \& R. Beck içinde, Business Transformation Through Blockchain Volume II, (s. 233-258). Palgrave Macmillan.

Tashmin, N. (2016). Art of Impression Management on Social Media. World Scientific News, 30, 89-102. .

Thomas, L. B. (2018). Exploring Digital Remediation in Support of Personal Reflection . International Journal of Human-Computer Studies, 110, 53-62.

Uluslararası Telekomünikasyon Birliği (ITU). (2018). Digital identity road map guide. https://www.itu.int/ITU-D/ICTApplications/Documents/Guides/ITU_ eID4D_DIGITAL\%20IDENTITY_ROAD_MAP_GUIDE_FINAL_Under\%20Review_ Until-05-10-2018.pdf. adresinden alındı

Wood, F. A., \& Smith, J. (2005). Online Communication Linking Technology (Second Ed. b.). Lawrence Erlbaum Associates Publishers. 


\section{Digital Identities and The Circle Film Analysis in the context of Goffman's Self Presentation Theory}

Sevgi Kavut (Ph.D.)

\section{Extended Abstract}

Communication has been one of the important requirements of humanity throughout history. Effective communication is the basis of modern societies. The world had to an undergoing change in the last two decades with the advent of pioneer technologies which societies transforming from analog to digital models. It is indicated that in the middle of the 21st century and the future our society will be certainly underlying more based upon artificial intelligence, big data-based and interconnected a world, social systems will stress blockchain-based connections and distributed databases of information infrastructure. In this context, The Circle film has been analyzed by using the film analysis method.

The purpose of this article is to present change and transformation process living because of digital identities and online communication technologies, their self-presentations, and position in people's life of digital identities and online communication technologies with examples from The Circle in the context of Goffman's self-presentation theory. As a consequence, it is found that examples concerning concepts Goffman's performances, showcase, teams, region and regional behavior, professional customer, observer and informant roles from discrepant roles, communication out of character and the art of impression management when The Circle film analyzed. It is believed that this article will contribute to the next studies as part of issues digital identity and digital awareness, digital communication, online and virtual environment, impression management, front stage and backstage behaviors, self-presentation.

Goffman discusses his self-presentation with both front-of-stage and behind-the-scenes behavior. Behind the scenes; front-of-stage performances are often more discreet and careful while reflecting a less constructed and less filtered version of individuals' selves (Smith, Sanderson, 2015: 343).

This research is limited to topics of digital identities, Goffman's theory of self-presentation, and The Circle film. Within the theoretical framework of the research, Goffman's theory of self-presentation was used. The film analysis method was used in the analysis process of the research.

Erving Goffman (2018) explained the concepts related to the theory of self-presentation in his book Presentation of Self in Daily Life under 6 headings as Performances, Teams, Regions and Regional Behaviors, Discrete Roles, Non-Character Communication, and The Art of Impression Management.

Performances: Performances are defined as all activities and actions of individuals who leave an impression on audiences and are presented ahead of observer masses. As for showcase has been defined as standard expressions that individuals willingly or unintentionally make during their performances. (Goffman, 2018: 33).

Teams: Teams are defined as an individual group that collaborates to present performances in front of audiences (Goffman, 2018: 80). 
Regions and Regional Behaviors: Goffman defines the region as a place surrounded by barriers to the perceptions of individuals as for the places where performances are performed as a showcase area (2018: 107-108).

Discrete Roles: Goffman explained that there are discrete roles used by actors while performing their performances and that these discrete roles are classified groups as a scout, informant, bait, professional customer, and intermediary (2018: 146).

Non-Character Communication: Goffman defined the concept of non-character communication as an interaction process established when actors exhibit themselves rather than they claim to perform. Goffman emphasized that individuals remain in the character they play when performing their performances with impression management (2018: 161).

The Art of Impression Management: Goffman defines the art of impression management as the basic functions that ensure that individuals' performances are not disrupted (2018: 196).

It is seen that the performances and showcases lived in the film have been included the scout, informant, and professional customer roles from Goffman's discrete roles in front of the stage.

Meanwhile, it is seen that the art of impression management is constituted for The Circle followers with provided advantages, technology superiorities of The Circle technology company, and so on.

In the last frame of the film, it can be suggested that with the showing of different cities, different cultures, and people in front of the cameras, everyone can see everyone, transparency comes to the fore, privacy decreases, front-of-stage and behind-the-scenes behaviors differ from each other, and a digital world where self-presentation and society of the spectacle come to the fore is intended to be pointed out that a digital world will exist soon.

All in all, when The Circle film was analyzed, it is found that examples concerning concepts of performance, showcase, teams, regions and regional behaviors, discrete roles from the scout, informant, professional customer, non-character communication, the art of impression management.

Keywords: Communication Studies, Digital Identity, New Communication Technologies, Film Analysis, The Circle, Self-Presentation Theory.

Bu makale intihal tespit yazilımlarıyla taranmıştır. Intihal tespit edilmemiş̧tir.

This article has been scanned by plagiarism detection softwares. No plagiarism detected.

Bu çalışmada "Yükseköğretim Kurumları Bilimsel Araştırma ve Yayın Etiği Yönergesi” kapsamında uyulması belirtilen kurallara uyulmuştur.

In this study, the rules stated in the "Higher Education Institutions Scientific Research and Publication Ethics Directive" were followed.

Çalışma tek bir yazar tarafından yürütülmüştür.

The study was conducted by one author.

Çalışma kapsamında herhangi bir kurum veya kişi ile çıkar çatışması bulunmamaktadır.

There is no conflict of interest with any institution or person within the scope of the study. 